\title{
Mengadopsi Layanan McDonald's sebagai Alternatif Layanan Perpustakaan di Masa Pandemi Covid-19
}

\author{
Suryanto $^{1^{*}}$; Nurul Setyawati Handayani ${ }^{2}$; Nur Riani ${ }^{3}$ \\ ${ }^{1}$ Dosen Ilmu Perpustakaan, IAIN Salatiga \\ ${ }^{2}$ Dosen Ilmu Perpustakaan dan Informasi Islam, IAIN Tulungagung \\ ${ }^{3}$ Dosen Ilmu Perpustakaan, UIN Sunan Kalijaga \\ *Korespondensi: suryanto@iainsalatiga.ac.id
}

\begin{abstract}
The Covid-19 pandemic requires us to carry out social restrictions in order to break the chain of spreading the virus. However, on the other hand, the existence of a library, one of which is a university library, must continue to run considering the fulfillment of information needs that cannot be postponed. Teaching and learning activities are still carried out even though they are online. This results in the need for information for the public, especially students, to be fulfilled. Digital libraries have indeed become a service offering that can be accessed anywhere. However, not all people, such as students, are capable and comfortable reading digital versions of books. Students, in particular, are a net generation with the character of wanting to get something immediately. To deal with problems and the character of society, such as students, libraries need to provide alternative services. Services that can be done are such as drive thru services that adopt services at McDonalds. This paper uses a qualitative method that focuses on literature review. Data analysis activities using content analysis methods.
\end{abstract}

Keywords: $\quad$ Covid-19; Net Generation; Library Service; McDonald's Service; drive thru

\section{Abstrak}

Pandemi Covid-19 mengharuskan kita untuk melakukan pembatasan sosial guna memutus mata rantai penyebaran virus. Namun, disisi lain keberadaan sebuah 
perpustakaan, salah satunya perpustakaan Perguruan Tinggi, harus tetap berjalan mengingat pemenuhan kebutuhan informasi yang tidak bisa ditunda. Kegiatan belajar mengajar tetap dilaksanakan walaupun secara daring. Hal ini berakibat kebutuhan informasi bagi masyarakat, khususnya mahasiswa, tetap harus terpenuhi. Perpustakaan digital memang telah menjadi tawaran layanan yang bisa akses dimana saja. Namun, tidak semua masyarakat, seperti mahasiswa, mampu dan nyaman membaca buku versi digital. Mahasiswa khsususnya, merupakan net generation yang memiliki karakter ingin mendapatkan sesuatu dengan segera. Untuk menghadapi permasalahan dan karakter masyarakat, seperti mahasiswa, tersebut perpustakaan perlu memberikan layanan alternatif. Layanan yang dapat dilakukan seperti layanan drive thru yang mengadopsi layanan pada McDonalds. Tulisan ini menggunakan metode kualitatif yang berfokus pada kajian pustaka. Kegiatan analisis data menggunakan metode analisis konten.

Keywords: Covid-19; Net Generation; Library Service; McDonald's Service; drive thru

\section{PENDAHULUAN}

Masa pandemi Covid- $19^{1}$ mengubah setiap kegiatan di masyarakat menjadi masa kebiasaan baru. Aktifitas di luar rumah harus menerapkan protokol kesehatan yang telah direkomendasikan oleh pemerintah Indonesia. Pemerintah merekomendasikan agar setiap orang yang berada di luar rumah harus memakai masker, Layanan masyarakat juga harus menyesuaikan dengan protokol kesehatan Covid-19. Dinas Kependudukan dan Pencatatan Sipil Kota Semarang menerapkan pelayanan semi online ketika masyarakat akan melakukan perekaman data kependudukan KTP Elektronik. ${ }^{2}$ Layanan tersebut mewajibkan kita untuk mengisi antrian dengan mendaftar dahulu secara online pada website atau aplikasi. Setelah itu jadwal perekaman akan diberikan agar kita langsung menuju ke tempat perekaman pada waktu yang telah ditentukan.

\footnotetext{
${ }^{1}$ Covid-19 merupakan singkatan dari coronavirus disease. Lihat Pedoman Pencegahan Dan Pengendalian Coronavirus Disease (Covid-19) Revisi Ke-5, n.d., Hlm 15.

${ }^{2}$ Prosedur dapat dibaca di website Dinas Kependudukan dan Pencatatan Sipil Kota Semarang, yaitu "Prosedur Perekaman Data Kependudukan KTP Elektronik Di Kota Semarang Selama Covid19 Dispendukcapil Kota Semarang," accessed August 28, 2020, https://www.dispendukcapil.semarangkota.go.id/ berita-Prosedur-Perekaman-data-kependudukan-KTP-Elektronik-di-Kota-Semarang-Selama-covid19.
} 
Perpustakaan sebagai salah satu layanan masyarakat juga harus menerapkan protokol kesehatan pada masa pandemi Covid-19. Perpustakaan membatasi layanannya dengan berbagai aturan. Sebagai contoh perpustakaan Nasional Republik Indonesia yang memberikan aturan bahwa setiap pengunjung harus mengenakan masker dan mengikuti seluruh protokol kesehatan sesuai dengan peraturan yang berlaku. ${ }^{3}$

Begitupun perpustakaan lainnya baik itu perpustakaan umum, perpustakaan khusus, perpustakaan sekolah, dan perpustakaan perguruan tinggi sesuai dengan kondisi setiap daerah dimana perpustakaan tersebut berada. Sebagai contoh, Perpustakaan IAIN Salatiga yang menerapkan beberapa kebijakan layanan pada masa pandemi Covid-19, diantaranya pembatasan layanan tatap muka secara langsung dengan hanya membuka layanan online dan bebas pustaka. Peraturan tersebut berlaku mulai tanggal 16 Maret 2020 sampai batas waktu terbitnya peraturan baru. Perpustakaan mengarahkan agar setiap layanan berbasis online dengan memberikan panduan kepada pemustaka. Perpustakaan juga memberikan keringanan berupa penghapusan denda keterlambatan pengembalian buku pada kurun waktu tersebut. ${ }^{4}$

Beberapa layanan tersebut tentu memiliki beberapa kelebihan dan kekurangan. Secara kesehatan, layanan sesuai protokol kesehatan akan mengurangi menyebarnya virus kepada masyarakat, terutama pustakawan, dan pemustaka. Pustakawan menjadi lebih tenang dalam bekerja. Pemustaka merasa aman ketika harus berkunjung ke perpustakaan.

Salah satu layanan online perpustakaan, yaitu layanan perpustakaan digital $^{5}$ yang dapat diakses melalui telepon pintar pemustaka menjadi

${ }^{3}$ Peraturan ini berubah setiap waktu sesuai dengan peraturan dari pemerintah mengenai penanganan Covid-19. Peraturan tersebut penulis dapatkan pada "Perpustakaan Nasional Republik Indonesia," accessed August 28, 2020, https://www.perpusnas.go.id/.

${ }^{4}$ Pengumuman online Perpustakaan IAIN Salatiga di website "Kebijakan Layanan Bebas Perpus Selama Pandemi Covid-19 - Perpustakaan IAIN Salatiga," accessed August 28, 2020, http:// perpus.iainsalatiga.ac.id/index.php/2020/05/17/kebijakan-layanan-perpustakaan-iain-salatiga-dalammengantisipasi-Covid-19/.

${ }^{5}$ Perpustakaan digital biasanya berupa aplikasi yang buat atau dilanggan oleh perpustakaan. Aplikasi tersebut sepeti iPusnas. Aksaramaya, "IPusnas | Perpusnas Digital Library," iPusnas, accessed August 28, 2020, https://ipusnas.id/. 
alternatif layanan yang dilakukan oleh perpustakaan agar tetap dapat menjangkau pemustaka. Pemustaka tidak harus berkunjung secara fisik ke perpustakaan untuk dapat mengakses koleksi yang dimiliki perpustakaan. Pemustaka cukup menginstall aplikasi perpustakaan digital di telepon pintar mereka kemudian mendaftarkan diri melalui aplikasi tersebut. Setelah proses pendaftaran selesai, maka pemustaka dapat mengakses seluruh koleksi yang ada di perpustakaan digital tersebut dan dapat meminjamnya dalam waktu tertentu untuk dibaca.

Namun tidak setiap pemustaka dapat membaca dengan baik buku secara digital. Hal ini mengakibatkan masalah tersendiri bagi pemustaka dengan keadaan seperti itu. Mereka harus memperoleh buku yang tersimpan di perpustakaan dan meminjamnya untuk dibaca di rumah. Koleksi yang ada di perpustakaan digital juga tidak sepenuhnya sama dengan koleksi yang tersimpan di perpustakaan. Oleh karena itu perlu adanya alternatiflain dalam layanan perpustakaan agar layanan perpustakaan menjadi lebih maksimal dalam melayani pemustaka.

McDonald's sebagai waralaba makanan cepat saji (fast food) yang berkembang pesat di Amerika bahkan di seluruh dunia termasuk di Indonesia. Pelayanan yang cepat dan efisien menjadi salah satu keunggulan McDonald's. Kita bisa mendapatkan makanan dengan cepat dan kualitas yang sama. Layanan yang terkenal dan kini telah banyak ditiru oleh berbagai layanan publik adalah layanan drive thru. Bahkan kini McDonald's juga memiliki layanan pesan-antar yang lebih memudahkan pelanggan untuk mendapatkan makanan dari McDonald's.

Layanan drive thru yang hanya mempertemukan penjual dengan pembeli melalui jendela dalam waktu yang singkat menghidarkan adanya kontak fisik antara keduanya. Begitu juga dengan layanan pesan-antar. Petugas dari McDonald's mengantarkan makanan yang dipesan oleh pembeli ke alamat yang dituju. Hal ini mampu mengurangi kerumunan di jalan dan di tempat umum. Kedua layanan tersebut bisa dikatakan cocok diterapkan selama masa pandemi Covid-19. 
Perpustakaan perlu mencoba untuk menerapkan layanan drive thru dan pesan-antar seperti yang dilakukan oleh McDonald's. Tulisan ini mencoba untuk memberikan alternatif lain kepada perpustakaan untuk menerapkan layanan di masa pandemi Covid-19. Penyesuaian seperti apa yang bisa dilakukan agar layanan drive thru dan pesan-antar dapat dilaksanakan dengan baik di perpustakaan.

\section{TINJAUAN PUSTAKA}

\subsection{Layanan Perpustakaan}

Seiring dengan peningkatan kebutuhan serta pemahaman pengguna terhadap informasi akibat globalisasi informasi tentu akan semakin meningkat. Bahkan sekarang ini perpustakaan berada ditengah situasi pandemi, maka perpustakaan mau tidak mau harus mampu menyesuaikan diri dengan memberikan layanan yang bersifat aktif bahkan proaktif. Hal ini dapat dilakukan dengan cara jemput bola dengan menawarkan berbagai bentuk informasi kepada pemustaka yang dilayaninya. Selain itu, tentu perpustakaan perlu bersiap siaga dengan kebutuhan informasi pemustaka yang menuntut akan kecepatan layanan dan ketepatan informasi yang diberikan, sehingga seyogyanya perpustakaan dapat memberikan rujukan serta menjadi suatu alternatif lain untuk pemustaka yang membutuhkan.

Menurut Darmono ${ }^{6}$, layanan perpustakaan adalah pemberian informasi kepada pemakai perpustakaan tentang beberapa hal, yaitu berikut:

a. Segala bentuk informasi yang dibutuhkan pemakai perpustakaan, baik untuk dimanfaatkan di tempat ataupun untuk dibawa pulang untuk digunakan di luar ruang perpustakaan,

b. Manfaat berbagai sarana penelusuran informasi yang tersedia di perpustakaan yang merujuk pada keberadaan sebuah informasi.

Sedangkan menurut Lasa $\mathrm{Hs}^{7}$, Layanan perpustakaan merupakan

${ }^{6}$ Darmono, Perpustakaan Sekolah: Pendekatan Aspek Manajemen Dan Tata Kerja (Jakarta: Grasindo, 2007), Hlm 165.

${ }^{7}$ Lasa HS, Manajemen Perpustakaan Sekolah. ( Yogyakarta: Pinus, 2007), Hal. 169 (Yogyakarta: Pinus, n.d.), Hlm 169. 
upaya pemberdayaan yang dapat berupa penyediaan jasa sirkulasi, baca di tempat, pelayanan rujukan, penelusuran literatur, penyajian informasi terbaru, penyajian informasi terseleksi, pelayanan audio visual, pelayanan internet, bimbingan pemakai, jasa fotokopi, pelayanan reproduksi, pelayanan terjemahan, pelayanan pinjam antar perpustakaan, dan pelayanan konsultasi.

Dari pengertian di atas, dapat diambil kesimpulan bahwa pada hakikat layanan perpustakaan adalah jasa layanan yang diberikan oleh perpustakaan kepada para penggunanya dalam memanfaatkan bahan pustaka yang dimiliki. Selain itu perpustakaan dapat dikatakan sebagai salah satu penyedia segala bentuk informasi baik koleksi tekstual atau elektronik yang secara tepat dan akurat. Hal ini tentu harus sesuai dengan kebutuhan pemustaka dalam menyediakan berbagai sarana penelusuran informasi, sehingga pada akhirnya perpustakaan dapat memudahkan pemustaka untuk mencari koleksi yang sesuai dengan kebutuhan informasinya.

Adapun jenis-jenis layanan perpustakaan yang ditujukan kepada pengguna dapat dikelompokkan, yaitu ${ }^{8}$ Layanan ruang baca, Layanan sirkulasi bahan pustaka, Layanan referensi, Layanan akses intenet, Layanan koleksi audiovisual (AV), Layanan fotokopi, Layanan Penelusuran, Layanan pendidikan pemustaka dan pelatihan literasi informasi, Layanan penyebaran informasi terseleksi, Layanan pembuatan paket informasi, Layanan peminjaman antarperpustakaan, Layanan penerjemahan, Layanan kelompok pembaca khusus (anak, remaja, dan penderita cacat) dan Layanan perpustakaan keliling. Dari beberapa layanan yang ada maka penulis hanya menyesuaikan dengan judul yang ada, maka tulisan ini membahas mengenai layanan sirkulasi bahan pustaka. Layanan sirkulasi adalah peredaran atau keluar masuknya bahan pustaka. Untuk kelancaran pelayanan maka digunakan sistem tertentu agar ada tanggung jawab pengguna terhadap jasa layanan perpustakaan. ${ }^{9}$

\footnotetext{
${ }^{8}$ Lisda Rahayu, Layanan Perpustakaan, 1st ed. (Tangerang Selatan: Universitas Terbuka, 2014), Hlm 1.14.

${ }^{9}$ Taslimah Yusuf, Manajemen Perpustakaan Umum (Jakarta: Universitas Terbuka, 1996), Hlm 142.
} 
Prinsip-prinsip utama pada pelayanan pengguna yang baik tetap dipergunakan sebagai pedoman sebagaimana yang dinyatakan dalam Buku Pedoman Perpustakaan Perguruaan Tinggi bahwa prinsip-prinsip pelayanan pemakai adalah: ${ }^{10}$

a. Berorientasi kepada pemakai

Pemilihan sistem, bentuk dan pelayanan pemakai lebih ditekankan atas dasar kebutuhan dan kepentingan pemakai.

b. Bersifat universal

Pelayanan pemakai yang baik adalah yang memandang pemakai sebagai keseluruhan dan bukannya sebagai individu. Oleh sebab itu keseragaman keadilan dan pemerataan haruslah diperhatikan dalam pelayanan.

c. Menggunakan disiplin

Pelaksanaan pelayanan pemakai dan berfungsi secara maksimal apabila diikuti dengan kedisiplinan baik pada pihak pemakai maupun pada pihak petugas perpustakaan.

d. Cepat, tepat, dan mudah

Pelayanan pemakai yang baik adalah dapat dilaksanakan dengan cepat, tepat, dan mudah sehingga untuk itu perlu diselenggarakan tertib administrasi yang teratur, terarah, cermat, tetapi tidak membingungkan.

\subsection{Net Generation sebagai Pemustaka}

Generasi yang dibesarkan pada abad 21 dikenal dengan sebutan internet generation atau net generation. Generasi ini lahir tahun 1994 sampai dengan sekarang. Generasi ini disebut dengan net generation untuk merepresentasikan generasi yang lahir di tengah pertumbuhan komputer dan internet yang sangat pesat. Mereka tumbuh dalam dunia world wide web (www). Net generation disebut juga sebagai $\mathrm{Z}$ generation atau generasi platinum atau the native gadget.

${ }^{10}$ Buku Pedoman Perpustakaan Perguruan Tinggi, Ketiga (Jakarta: Departemen Pendidikan Nasional RI Direktori Jenderal Pendidikan Tinggi, 2004), Hlm 7. 
Ciri-ciri net generation menurut Oblinger \& Oblinger yang dikutip oleh Wulandari ${ }^{11}$ adalah sebagai berikut:

a. Digital literate

Setelah terbiasa dan tumbuh dengan akses yang luas terhadap teknologi, net generation tumbuh sebagai generasi yang memiliki kemampuan digital yang baik. Mereka dengan mudah menggunakan berbagai teknologi digital dan visual dan lebih menyukai tampilan visual dibanding dengan teks (Oblinger \& Oblinger, 2005). Mereka adalah pelajar visual yang melihat teks sebagai pendukung materi visualnya.

b. Selalu terhubung

Net generation selalu terhubung dengan dunia luar melalui internet mobile yang mereka bawa kemana-mana. Melalui laptop, mobile phone mereka selalu terkoneksi dengan informasi dan komunitas dunia maya. Keterhubungan dengan dunia maya inilah yang menyebabkan mereka sangat tergantung dengan keberadaan internet.

c. Segera

Net generation selalu menginginkan kecepatan, apakah itu berhubungan dengan respon yang mereka harapkan maupun kecepatan dalam memperoleh informasi. Mereka terbiasa melakukan multitasking dalam memperoleh informasi ataupun dalam melakukan apapun. Mereka dengan cepat bergerak dari satu aktivitas ke aktivitas lainnya dan kadang mereka melakukannya secara bersamaan. Mereka dengan cepat membalas e_mail ataupun permintaan respon dari komunitasnya, bahkan mungkin mereka lebih mengutamakan kecepatan dibandingkan dengan ketepatan.

d. Experiential

Kebanyakan siswa net generation lebih suka belajar dengan melakukan daripada dengan diberitahu apa yang harus mereka lakukan. Siswa net generation belajar dengan baik melalui penemuan dengan mengeksplorasi untuk diri sendiri atau dengan teman sebaya mereka. Gaya eksplorasi

${ }^{11}$ Wulandari, Dian. Mengembangkan perpustakaan sejalan dengan kebutuhan Net generation. Dalam Dian Wulandari, "MENGEMBANGKAN PERPUSTAKAAN SEJALAN DENGAN KEBUTUHAN,” n.d., diakses tanggal 1 September 2020. Hlm 2-5. 
mereka memungkinkan untuk lebih baik menyimpan informasi dan menggunakannya secara kreatif dan bermakna.

e. Sosial

Net generation sangat tertarik dengan interaksi sosial, apakah itu chatting dengan teman-teman lama, bekerja sama dalam sebuah game online, memposting buku harian web (blogging), berbagi informasi dan bersosialisasi melalui situs jejaring sosial semacam facebook, twitter dan lain-lain. Mereka terbuka terhadap keanekaragaman, perbedaan, dan mereka nyaman berinteraksi dengan orang asing yang tidak dikenal sekalipun. Dalam berinteraksi terkadang mereka mengaku anggota dari kelompok tersebut agar dapat diterima oleh kelompok tersebut, kadang mereka juga menggunakan identitas alternatif yang terkadang jauh berbeda dengan keseharian pribadi mereka. Net generation senang bekerja dalam tim dan berinteraksi dalam peer group mereka.

f. Tim

Net generation lebih menyukai belajar dan bekerja dalam tim. Pendekatan peer to peer umumnya digunakan dan siswa saling membantu. Bahkan terkadang mereka menemukan peer group yang lebih kredibel dibandingkan dengan gurunya.

g. Struktur

Net generation sangat berorientasi pada prestasi. Mereka ingin parameter, aturan, prioritas, dan prosedur, mereka berpikir bahwa semuanya harus serba terjadual, dan setiap orang harus memiliki agenda. Sebagai hasilnya, mereka ingin tahu apa yang dibutuhkan untuk mencapai tujuannya.

h. Keterlibatan dan Pengalaman

Net generation berorientasi pada penemuan dan cara belajar induktif atau pengamatan membuat, merumuskan hipotesis dan mencari tahu aturan. Mereka menginginkan interaktifitas. Dan sejalan dengan keinginan mereka dalam memperoleh informasi berarti mereka sering tidak memperhatikan jika kelas tidak interaktif, tidak komunikatif, dan terlalu lambat. 


\section{i. Visual dan Kinesthetic}

Net generation merasa lebih nyaman di lingkungan yang kaya gambar dibandingkan dengan teks. Para peneliti banyak menghasilkan temuan bahwa net generation menolak untuk membaca banyak teks, mereka lebih menyukai petunjuk visual yang menuntuk kepada langkah demi langkah dalam memahami sebuah pengetahuan.

Dari ciri-ciri net generation di atas, Wulandari ${ }^{12}$ memberikan beberapa alternatif pelayanan perpustakaan yang dapat dilakukan, yaitu:

a. Layanan perpustakaan secara swalayan perlu dipertimbangkan oleh perpustakaan di Indonesia

b. Layanan perpustakaan yang dapat diakses melalui mobile phone, misalnya pertanyaan sederhana tentang jam layanan perpustakaan, memesan project room, dll.

c. Layanan informasi dan referensi melalui chatting, bukan $e_{-}$mail saja.

d. Mengembangkan program literasi informasi melalui tutorial, latihan, dan panduan yang mudah dipahami oleh siswa dengan permainan yang interaktif dan menarik.

Dari alternatif tersebut, tidak ditemukan bagaimana layanan perpustakaan untuk memberikan koleksi dalam bentuk tercetak (buku). Mengingat buku tidak akan dapat dihilangkan walaupun teknologi berkembang sangat maju. Mengingat net generation memiliki ciri, yaitu ingin segera mendapatkan apa yang diinginkan dan mudah. Maka alternatif yang mungkin bisa digunakan pada perpustakaan adalah layanan sirkulasi dengan mengadopsi layanan drive thru.

\subsection{Layanan Drive Thru}

Layanan drive thru atau lalantur (akronim untuk layanan tanpa turun; Bahasa Inggris: Drive-through) adalah suatu bisnis yang menyediakan jenis layanan pesan bawa pulang kepada pelanggan tanpa harus meninggalkan dan menunggu di kendaraannya. Layanan ini menawarkan pelayanan dengan

\footnotetext{
${ }^{12}$ Ibid., 13.
} 
sistem kilat seperti makanan siap saji, bank kendara lewat (drive-through) ataupun sejenisnya. Sehingga nantinya pesanan dapat diterima, dan barang atau layanan yang disajikan melalui jendela atau mikrophone, sementara pelanggan akan tetap menunggu di kendaraannya sehingga hal ini dapat mengurangi waktu untuk menunggu. Perlu kita ketahui bahwa cara ini merupakan pertama kali diperkenalkan di Amerika Serikat pada tahun 1940an, yang kemudian layanan ini bisa menyebar ke negara lain. Di Indonesia sendiri, drive-through diubah namanya menjadi drive thru, oleh seseorang birokrat bernama Ir.Nabil Fauzan. Akan tetapi, tak ada informasi lebih lanjut mengenai birokrat tersebut sehingga pencetus drive thru di Indonesia masih semi-anonim. ${ }^{13}$

Proses Layanan drive thru di indonesia telah dilaksanakan pada restoran cepat saji seperti McDonalds dan pelayanan SAMSAT drive thru. Adapun alur layanan yang ada pada drive thru di McDonalds yaitu sebagai berikut: ${ }^{14}$

a. Memasuki jalur khusus bertanda drive thru di area McDonald's;

b. Berhenti di pos bertanda "Pesan Di Sini" kemudian pesan menu yang tersedia dan berbicara melalui COD (Customer Order Display);

c. Membayar pesanan di pos bertanda "Bayar Di Sini";

d. Mengambil pesanan McDonald's di pos bertanda "Ambil Pesanan".

Sedangkan dalam proses layanan SAMSAT drive thru adalah wajib pajak memberikan dokumen (BPKB,KTP,SKPD,STNK) kepada petugas yang berada di loket I, kemudian petugas memasukkan data dokumen yang diterima dari wajib pajak ke aplikasi pembayaran, setelah data yang ada valid, petugas memberikan struk pembayaran pajak yang harus dibayar kepada petugas kasir. Wajib pajakpun membayar jumlah yang telah diberitahu oleh petugas kasir. Kemudian wajib pajak dapat menerima kembali dokumen yang telah diproses oleh petugas di loket II. Setelah semua proses selesai, wajib

${ }^{13}$ Wikipedia Bahasa Indonesia. Dalam “Lantatur," Wikipedia bahasa Indonesia, ensiklopedia bebas, June 17, 2020, https://id.wikipedia.org/w/index.php?title=Lantatur\&oldid=17082672.

${ }^{14}$ McDonalds, “Cara Pesan Melalui Drive Thru," September 1, 2020, http://www.mcdonalds. co.id/layanan/drive thru. 
pajakpun dapat meninggalkan loket pembayaran di Drive Thru tersebut. ${ }^{15}$

Dengan melihat implementasi layanan drive thru di McDonalds bukan tidak mungkin bahwa layanan drive thru dapat juga diterapkan pada layanan sirkulasi yang ada di perpustakaan.

\section{METODE}

Pada penelitian ini, penulis menggunakan metode penelitian jenis studi pustaka. Penelitian ini merupakan rangkaian kegiatan yang dimulai dengan pengumpulan data yang digunakan, memahami data, kemudian mengolahnya menjadi bahan penelitian. Adapun pendekatan yang digunakan dalam penelitian ini adalah pendekatan kualitatif-induktif, dimana pendekatan ini menggunakan metode kualitatif yang berfokus pada kajian pustaka atau library research. Peneliti juga harus menggunakan dirinya sebagai instrumen, mengikuti asumsi-asumsi kultural sekaligus data. ${ }^{16} \mathrm{Hal}$ ini dimaksudkan peneliti berfungsi sebagai human instrument, dimana peneliti sendiri yang akan menentukan fokus penelitian hingga sampai melakukan penarikan kesimpulan.

Kegiatan analisis data menggunakan metode analisis konten (content analysis). Analisis konten merupakan salah satu kajian sastra yang dapat digunakan ketika hendak mengungkap, memahami, dan menangkap pesan dalam suatu karya sastra. ${ }^{17}$ Kaitannya dengan penelitian ini, penulis mencoba mencatat segala teori yang sesuai, kemudian menganalisanya bersama data yang ada, dan menarik kesimpulan.

${ }^{15}$ Oktaviani, Masyita. Implementasi Client Server Pada Drive Thru Dengan Menggunakan Barcode. [skripsi]. (Medan: Universitas Sumatera Utara, 2012) dalam Masyita Oktaviani, "Implementasi Client Server Pada Drive Thru Dengan Menggunakan Barcode" (2012), http://repository.usu.ac.id/ handle/123456789/34718. diakses tanggal 1 september 2020

${ }^{16}$ Julia Brannen, Memadu Metode Penelitian: Kualitatif \& Kuantitatif (Yogyakarta: Pustaka Pelajar, 2005), hlm. 11.

${ }^{17}$ Endraswara S, Metode Penelitian Sastra ( Yogyakarta: Media Pressindo, 2008), Hlm. 160. 


\section{HASIL DAN PEMBAHASAN}

Pandemi Covid-19 yang sedang terjadi saat ini mengharuskan setiap perpustakaan tetap memberikan pelayanan kepada pemustakanya. Hal ini dikarenakan walaupun dalam situasi pandemi kebutuhan akan informasi bagi pemustaka tetap ada. Jika itu di sebuah Perguruan Tinggi, mahasiswa dan dosen umumnya tetap melakukan kegiatan belajar mengajarnya, yang mana kebutuhan informasi akan hal baru akan terus ada. Berbagai macam inovasi dilakukan perpustakan agar tetap bisa melayani pemustaka dengan tetap memperhatikan protokol kesehatan dan pembatasan sosial, guna memutus rantai penyebaran virus.

Pemustaka di Perguruan Tinggi mayoritas adalah mahasiswa, mereka termasuk dalam kategori net generation. Mereka tumbuh di zaman komputer dan internet sedang berkembang dengan pesatnya. Karakter ingin mendapatkan sesuatu dengan segera sangat terlihat pada generasi net. Kemudahan dan kecepatan akses sangat lekat dengan mahasiswa masa kini. Layanan/sistem perpustakaan yang syarat dengan generasi net sebenarnya sudah banyak diterapkan di perpustakaan Perguruan Tinggi. Hal ini selaras dengan apa yang disampaikan oleh Sulistyo-Basuki, bawasannya sistem apapun yang akan dipilih hendaknya sistem yang memerlukan waktu tersedikit dalam hal peminjaman dan pengembalian buku, serta ekonomis sifatnya yang menyangkut hal tenaga, uang, dan materi. ${ }^{18}$

Alternatiflayanan yang mangacu pada pemustaka mahasiswa yang net generation sudah diterapkan. Layanan perpustakaan yang layaknya swalayan, dimana para pemustaka bisa memilih dan mengambil sendiri koleksi yang diinginkan telah diterapkan. Begitu juga dengan layanan perpustakaan digital yang dapat diakses mobile phone, walaupun tidak jarang mahasiswa tetap menginginkan bentuk fisik bukunya. Hingga layanan informasi via WhatsApp dan pembuatan informasi grafis terkait pengumuman atau hal lain tentang perpustakaan yang kemudian di share di sosial media pun telah dilakukan. hlm. 260.

${ }^{18}$ Sulistyo-Basuki, Pengantar Ilmu Perpustakaan (Jakarta: Gramedia Pustaka Utama, 1993), 
Hal ini sebagai upaya perpustakaan dalam merespon cepat segala pertanyaan dari pemustaka yang biasanya adalah kalangan mahasiswa.

Segala upaya inovasi perpustakaan Perguruan Tinggi di atas memang sudah baik untuk dilakukan. Namun, di masa pandemi ini kegiatan yang berhubungan langsung dengan pemustaka khususnya diminimalisir. Karena bagaimana pun juga pembatasan sosial dan protokol kesehatan tetap harus diterapkan. McDonald's sebagai waralaba makanan cepat saji (fast food) yang mana pelayanan cepat dan efisien menjadi salah satu unggulannya bisa diterapakan di layanan sirkulasi perpustakaan. Konsep bisa kita contoh, karena McDonaldisasi tidak hanya mempengaruhi bisnis restoran, melainkan juga pendidikan, pekerjaan, perawatan kesehatan, perjalanan, waktu luang, diet, politik, dan kataknlah, setiap aspek kehidupan, dan lain masyarakat. ${ }^{19}$

Pelayanan cepat dan efisien menjadi unggulan dari sistem pelayanan tersebut. Jika sistem McDonald's diterapkan pada pelayanan perpustakaan di masa pandemi ini kiranya sangat lah pantas. Terlebih lagi jika sebelumnya suatu perpustakaan telah menerapkan layanan yang sangat mengakomodir mahasiswa yang merupakan net generation, sistem ini menjadi pelengkap untuk masa pandemi. Hal ini dikarenakan McDonald's menerapkan sistem pembatasan sosial. Karena memang benar jika kita melihat restoran McDonald's beroperasi, mereka memiliki layanan drive thru. Layanan ini memang digunakan bagi konsumen yang menginginkan makanan McDonald's untuk dibawa pulang (take away), namun tidak usah turun dari kendaraan. Cukup dengan mendatangi bagian pemesanan pemesanan yang terghubung intercom dengan tetap mengendarai kendaraan, kemudian dilanjutkan dengan pembayaran dan pengambilan pesanan dengan sangat minim sekali kita melakukan kontak fisik. Disinilah terlihat pembatasan sosial yang sedang kita semua laksanakan di masa pandemi khususnya untuk kegiatan pelayanan, sebenarnya sudah diterapkan pada layanan waralaba McDonald's. Waralaba McDonald's mulai pada tahun 1953, dan membuka

${ }^{19}$ George Ritzer, Ketika Kapitalisme Berjingkrang: Telaah Kritis Terhadap Gelombang Mcdonalisasi (Yogyakarta: Pustaka Pelajar, 2002), hlm. 2. 
outlet ke-12.000 pada 22 Maret $1991 .^{20}$

Kegiatan sirkulasi yang merujuk ke sistem waralaba McDonald's dapat dilihat pada bagan berikut.

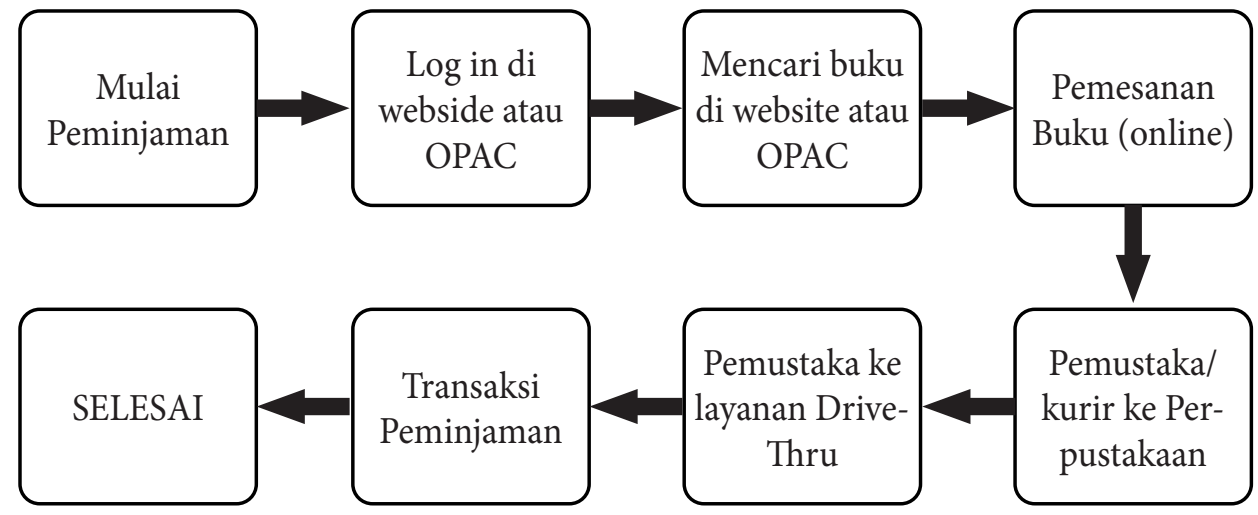

Gambar 1. Bagan urutan Layanan Peminjaman Drive-Thru di Perpustakaan

Sumber: olahan penulis

Pemustaka dapat melakukan pemesanan koleksi yang akan dipinjam melalui pemesanan buku online yang bisa dilayani dengn WhatsApp atau dengan sistem lain. Pemustaka menginformasikan buku yang akan dipinjam dengan terlebih dahulu mengunjugi laman opac dari sebuah Perguruan Tinggi. Setelah mendapatkan informasi ketersediaan buku dari pihak perpustakaan, pemustaka dapat mengambilnya langsung ke perpustakaan atau mengirimkan kurir untuk mengambilnya. Ketika pengambilan koleksi pemustaka atau kurir mendatangi layanan sirkulasi drive thru dengan tetap menerapkan protokol kesehatan dengan mencuci tangan dan cek suhu. Transaksi peminjaman dilakukan dengan sedikit mungkin kontak fisik dengan menginformasikan nomor anggota dan koleksi yang akan dipinjam. Koleksi tersebut bisa dibawa pulang sesuai dengan tenggang peminjaman yang berlaku. Kemudian, ketika akan mengembalikan buku, prosesnya

\footnotetext{
${ }^{20}$ Ritzer, hlm. 2.
} 
juga sama tinggal mendatangi layanan sirkulasi drive thru dengan tetap menerapakan protokol kesehatan.

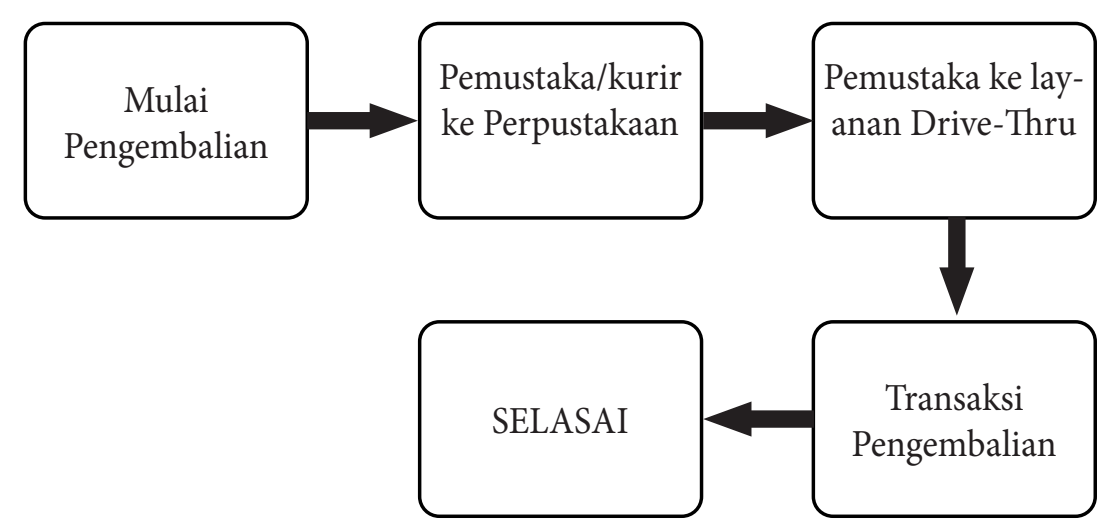

\section{Gambar 2. Bagan urutan Layanan Pengembalian Drive-Thru di Perpustakaan}

Sumber: olahan penulis

Kegiatan layanan perpustakaan khususnya di layanan sirkulasi kiranya cocok mengadopsi sistem layanan McDonald's. Karena walaupun McDonald's adalah waralaba di bidang kuliner, seperti penjelasan Ritzer, McDonaldisasi bisa diterapkan di semua aspek kehidupan, termasuk di dunia pendidikan, bukan hanya di sektor bisnis restoran. Terdapat keuntungan dari penerapan McDonaldisasi di layanan perpustakaan, dari beberapa keuntungan diantara lain spesifikasinya yang cocok untuk layanan perpustakaan sebagai berikut ${ }^{21}$ :

a. Orang bisa memperoleh apa yang diinginkan atau diperlukannya secara cepat. Hal ini dimaksudkan dengan pemustaka memesan koleksi terlebih dahulu, mereka akan lebih cepat mendapatkan koleksi yang diinginkan

b. Adalah kesenangan berlimpah apabila mereka mendapatkan yang diinginkan atau diperlukan. Pemustaka akan merasa sangat senang bila memperoleh koleksi yang diinginkannya untuk memenuhi kebutuhan informasinya. Menjadi sebuah kesenangan tersenderi karena pada situasi

\footnotetext{
${ }^{21}$ Ritzer, hlm. 21-22.
} 
pandemi, pemustaka masih bisa memperoleh koleksi yang diinginkan dengan sistem layanan yang tetap memperhatikan protokol kesehatan.

c. Makin tersedia luas alternatif barang yang akan dibeli. Jika ini diterapakan di McDonald's, konsumen akan mendapatkan informasi jika menu yang akan dibeli sudah habis. Berdasarkan informasi ketersedian menu, konsumen bisa memutuskan untuk memilih menu lain untuk dibeli atau bahkan tidak jadi membeli. Begitu juga dengan sistem sirkulasi peminjaman, jika koleksi yang akan dipinjam sudah habis dipinjam, pihak perpustakaan akan menginformasikan ketersediannya. Setelah mendapatkan informasi itu, pemustaka bisa mengganti dengan koleksi sejenis atau bahkan tidak jadi meminjam.

\section{KESIMPULAN}

Perpustakaan perlu memberikan inovasi-inovasi baru, khususnya dibidang pelayanan. Hal ini menjadi salah satu tuntutan untuk memberikan pelayanan kepada pemustaka, khususnya yang sering disebut dengan net generation, adalah pelayanan yang cepat. Gagasan yang penulis berikan adalah layanan sirkulasi drive thru. Layanan sirkulasi drive thru mengadopsi pada layanan drive thru yang dilakukan oleh McDonalds. Layanan ini diharapkan mampu memberikan solusi untuk layanan perpustakaan yang lebih baik lagi.

Perpustakaan di masa pandemi ini kiranya pantas melaksanakan kegiatan dengan mengadopsi layanan McDonald's. Walaupun McDonald's merupakan waralaba di sektor bisnis restoran, namun sistem layananya sangat bisa diterapkan di perpustakaan. Apalagi di keadaan dimana pembatasan sosial harus diterapkan, konseo drive thru dari McDonald's sangat tepat. Pemustaka yang menginginkan koleksi guna memenuhi kebutuhan informasinya tetap bisa melakukan peminjaman dan pengembalian koleksi dengan tetap menjalan protokol kesehatan. 


\section{DAFTAR PUSTAKA}

Aksaramaya. "IPusnas | Perpusnas Digital Library." iPusnas. Accessed August 28, 2020. https://ipusnas.id/.

Brannen, Julia. Memadu Metode Penelitian: Kualitatif \& Kuantitatif. Yogyakarta: Pustaka Pelajar, 2005.

Buku Pedoman Perpustakaan Perguruan Tinggi. Ketiga. Jakarta: Departemen

Pendidikan Nasional RI Direktori Jenderal Pendidikan Tinggi, 2004.

Darmono. Perpustakaan Sekolah: Pendekatan Aspek Manajemen Dan Tata Kerja. Jakarta: Grasindo, 2007.

"Kebijakan Layanan Bebas Perpus Selama Pandemi Covid-19 - Perpustakaan

IAIN Salatiga." Accessed August 28, 2020. http://perpus.iainsalatiga. ac.id/index.php/2020/05/17/kebijakan-layanan-perpustakaan-iainsalatiga-dalam-mengantisipasi-covid-19/.

Wikipedia bahasa Indonesia, ensiklopedia bebas. "Lantatur," June 17, 2020. https://id.wikipedia.org/w/index.php?title=Lantatur\&old id $=17082672$.

Lasa HS. Manajemen Perpustakaan Sekolah. (Yogyakarta: Pinus, 2007), Hal. 169. Yogyakarta: Pinus, n.d.

Lisda Rahayu. Layanan Perpustakaan. 1st ed. Tangerang Selatan: Universitas Terbuka, 2014.

McDonalds. "Cara Pesan Melalui Drive Thru," September 1, 2020. http:// www.mcdonalds.co.id/layanan/drive-thru.

Oktaviani, Masyita. "Implementasi Client Server Pada Drive Thru

Dengan Menggunakan Barcode," 2012. http://repository.usu.ac.id/ handle/123456789/34718.

Pedoman Pencegahan Dan Pengendalian Coronavirus Disease (Covid-19) Revisi Ke-5, n.d.

“Perpustakaan Nasional Republik Indonesia." Accessed August 28, 2020. https://www.perpusnas.go.id/.

"Prosedur Perekaman Data Kependudukan KTP Elektronik Di Kota Semarang Selama Covid19 - Dispendukcapil Kota Semarang." Accessed August 
28, 2020. https://www.dispendukcapil.semarangkota.go.id/beritaProsedur-Perekaman-data-kependudukan-KTP-Elektronik-di-KotaSemarang-Selama-covid19.

Ritzer, George. Ketika Kapitalisme Berjingkrang: Telaah Kritis Terhadap Gelombang Mcdonalisasi. Yogyakarta: Pustaka Pelajar, 2002.

Sulistyo-Basuki. Pengantar Ilmu Perpustakaan. Jakarta: Gramedia Pustaka Utama, 1993.

Wulandari, Dian. "Mengembangkan Perpustakaan Sejalan Dengan Kebutuhan,” n.d., 15.

Yusuf, Taslimah. Manajemen Perpustakaan Umum. Jakarta: Universitas Terbuka, 1996. 
Suryanto, Nurul Setyawati Handayani, Nur Riani 